\title{
STUDY ON THE CHARACTERISTICS OF CATALYTIC COMBUSTION FURNACE OF NATURAL GAS AND INFLUENCE OF ITS EXHAUST GAS TO PLANT
}

\author{
Shihong Zhang*, Fangjing Jia, Rui Zhang \\ School of Environment and Energy Engineering, Beijing University of Civil Engineering and Arch., Beijing, 100044, China
}

\begin{abstract}
This article discussed the radiation and pollutant emissions characteristics of the catalytic combustion furnace based the combustion of lean natural gas-air mixtures in catalytic honeycomb monoliths and the influence of its exhaust gas on schefflera plants growth by means of theory and experiments. The radiation efficiency of the monolith alone varied from approximately $20 \%$ to $40 \%$. The glazed tiles heated by the catalytic combustion furnace are more fine and glossy than that of conventional ones. Schefflera plants in experimental group in a greenhouse filling with catalytic combustion exhaust gas. On contrary, schefflera plants in control group stay in indoor environment. The result showed that schefflera plants in experimental group grow faster than that in control group, even greener. The content of pollutants in the exhaust gas of furnace and the date of the parameter of temperature, humidity and the concentration of $\mathrm{CO}_{2}$ in greenhouse were measured. Catalytic combustion as a developing technology could make the pollutant emissions ( $\mathrm{CO}$ and $\mathrm{NO}$ ) to near zero. The exhaust gas with high $\mathrm{CO}_{2}$ concentration could promote the growth of plants.

Keywords: Catalytic combustion furnace; Radiation; $\mathrm{CO}_{2}$ concentration; Plant.
\end{abstract}

\section{INTRODUCTION}

Air pollution is a critical environmental issue for the world, which is also a global problem with far-reaching environmental impacts. These mainly related to the traffic sector, but also regarding the industrial and residential combustion sectors (Duque et al., 2016). Recent epidemiologic studies have shown that ambient air pollution exposure is associated with increased mortality and higher incidence diseases such as asthma, chronic obstructive pulmonary disease, and cancer (Cohen et $a l ., 2005)$. When the first scientist examined the effect of air pollution on health after the Meuse Valley fog in 1930 or the London smog in 1952, no one could have known what an extended field of research they started (Rückerl et al., 2011).

Because of the great interest in a process which both reduced combustion pollutant emissions and also improved thermal efficiency, many research programs resulted (Pfefferle and Pfefferle, 1987). Catalytic combustion has been known since 1818, Sir Humphrey Davies observed that coal-gas and oxygen were able to sustain a combustion reaction on a platinum wire in the absence of a flame, giving off thermal radiation from the wire in its place. Heterogeneously catalyzed gas-phase combustion or catalytically stabilized combustion was first demonstrated by Pfefferle in 1970 (Pfefferle, 1975) and was shown to be an efficient method for burning fuels in lean fuel-air mixtures without significant formation of pollutants (Pfefferle, 1975; Pfefferle, 1978; Zhang et al., 2010).

The combustion of hydrocarbons contributes to a large part of air pollutant and the formulation of particulate matter (PM), however, catalytic devices for complete low-temperature oxidation of hydrocarbons were employed in various areas in place of traditional flaring devices and had the following advantages over the conventional heat sources: complete combustion of the fuel, which enhanced combustion efficiency; lower combustion temperature (Kirillov et al., 2003).

At present, the research of catalytic combustion technology was mainly related to the preparation of the catalyst, while the research of the application of catalytic combustion technology was few relatively. Recently, Anna-Karin Jannasch (Jannasch et al., 2006) constructed and evaluated a new Catalytic burner prototype, based on Catator's patented wire mesh catalysts, for natural gas combustion in gas cooking stoves. The results were very promising with respect to the catalyst life-time (>10 $000 \mathrm{~h}$ ), the NOx and the CO-emissions was low. In addition, a relatively high thermal efficiency could be measured over abroad range of power inputs(around40-50\%for1-4 kW). The catalytic combustion of $\mathrm{CH}_{4} /$ air mixtures over Pd-based catalysts was investigated experimentally and numerically at gas turbine relevant conditions (pressures up to 15bar and inlet temperatures up to 723K) in a reactor comprising of alternately coated channels. A global catalytic reaction rate was deduced, valid for catalyst temperatures below the PdO decomposition temperature (Carroni et al., 2003). Fibers obtained using the PVB/cerium nitrate reached higher conversions of methane, indicating higher catalytic activity. The electrospun fiber produced small amounts of nitrogen compounds during the catalytic combustion of methane (Pontelli et al., 2011). In the present study the radiation and pollutant emissions characteristics of the catalytic combustion furnace were concerned. To better understand the environmental effects of catalytic combustion, influence of its exhaust gas to plant was also conducted.

\footnotetext{
*Corresponding author. Email: shihongzhang@bucea.edu.cn.
} 


\section{EXPERIMENTAL SET-UP}

Figure 1 illustrates the system diagram of catalytic combustion furnace. The furnace body had the shape of a cuboid, whose edges were $500 \mathrm{~mm}$ long, $500 \mathrm{~mm}$ wide and $660 \mathrm{~mm}$ high. It was connected to the catalytic burner. The support for all the monoliths tested here was cordierite and its softening temperature was $1380{ }^{\circ} \mathrm{C}$. The two square catalytic honeycomb monoliths were installed in the burner each time. The square honeycomb monoliths were $150 \mathrm{~mm}$ wide and $20 \mathrm{~mm}$ long, with square-shaped cells which sectional area was $1 \mathrm{~mm} \times 1 \mathrm{~mm}$. In order to decrease the temperature of mixtures in chamber connected with the monolith's entrance, the $20 \mathrm{~mm}$ long blank monoliths were inserted between the chamber and the Pd based catalytic monolith's entrance as assembly of monolith.

The reactant gas feeds of natural gas and air were regulated via GMS0050BSRN200000 natural gas meter and CMG400A080100000 air meter with $0 \sim 50 \mathrm{~L} / \mathrm{min}$ and $0 \sim 80 \mathrm{~m}^{3} / \mathrm{h}$ of full-scale ranges, respectively. The two meters were provided by electric current. The cooling circulating water was used to cool the burner chamber.

The sampling line of exhaust gas from furnace vent consisted of a probe, taking an average exhaust sample, followed by tubing. Exhaust gas went into the greenhouse in which the schefflera plant was settled in. To supplement the data, mixed gas in the greenhouse also was analyzed by the exhaust gas analyser and the air parameter was recorded by digital thermo-hygrometer, offering the information of ambience which plant was in. During the experiment, glazed tiles in furnace had still been heated. First of all, we divided four same growth statement schefflera plants into two groups, experimental group and control group. Schefflera plant in experimental group stay in a greenhouse filling with catalytic combustion exhaust gas, on contrary, schefflera plant in control group stay in general environment. All plants watered equally and kept recording their statement should be made sure.

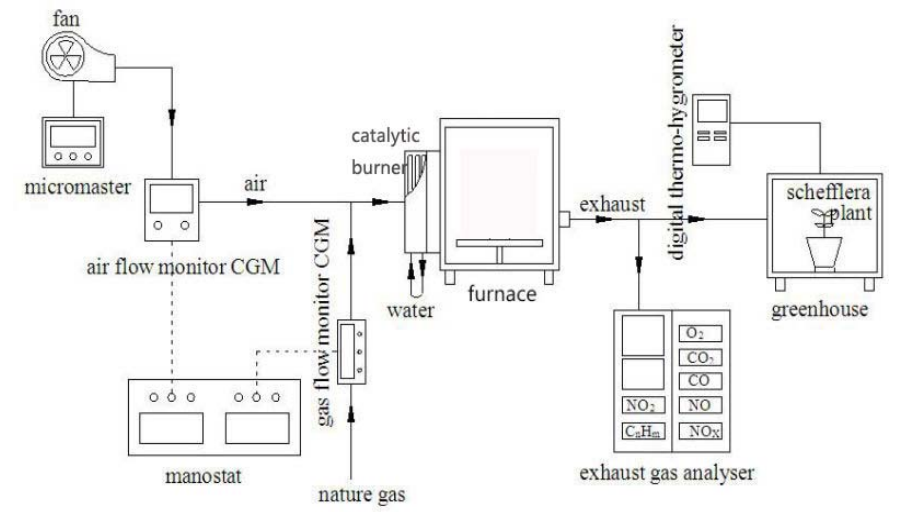

Fig. 1 The system diagram of catalytic combustion furnace

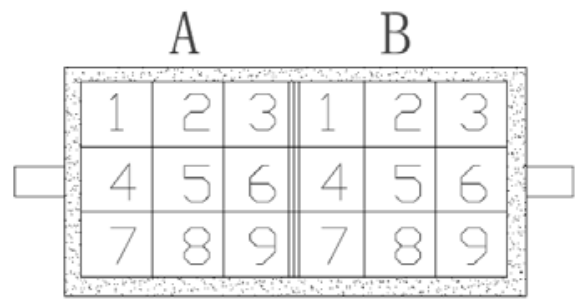

Fig. 2 Surface of the two monoliths

As shown in Fig. 2, the surface of the two monoliths was divided into eighteen uniform regions with the sectional area of $50 \mathrm{~mm} \times 50 \mathrm{~mm}$. The local surface temperature of catalytic monolith was measured by UX-20P infrared radiation thermometer with $600 \sim 3000^{\circ} \mathrm{C}$ of full-scale ranges. And the exhaust gas temperature at open end of monolith was measured by type thermocouple $\mathrm{K}$ of diameter 0.5 .

\section{EXPERIMENTAL RESULT AND DISCUSSION}

\subsection{The radiation outputs of the monoliths}

Figure 3 plots average local surface temperature of monolith and average gas temperature at the open end of monolith between 4 and $13.09 \mathrm{~kW}$ in thermal input of catalytic burner. As we can see from the profiles, average local surface temperature and average gas temperature ascended gradually with the increasing thermal input firstly, then their temperature began to decrease when the thermal input reached $12 \mathrm{~kW}$. The combustion was stable between $4 \mathrm{~kW}$ and $10 \mathrm{~kW}$. But a part area of catalyst became black gradually at $13.09 \mathrm{~kW}$.

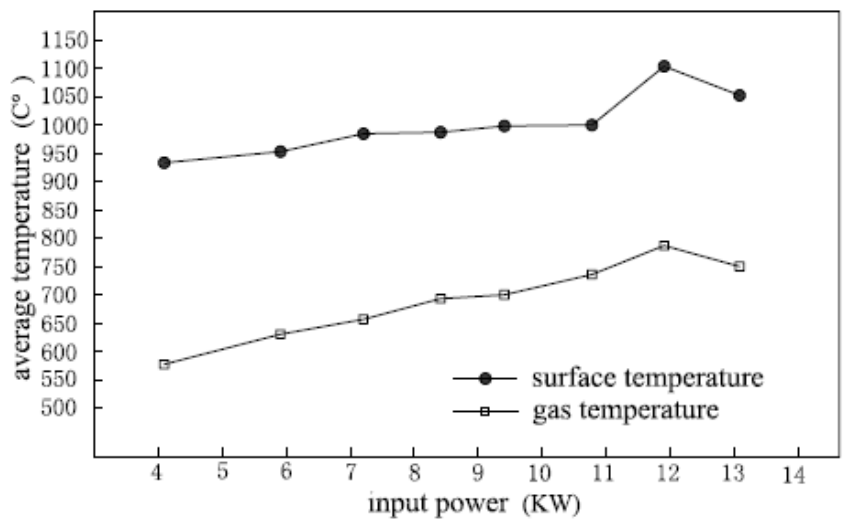

Fig. 3 Curves of average local surface temperature of monolith and average gas temperature at open end of monolith

The radiation outputs of the monoliths studied here were calculated based on the surface temperatures measured by the infrared pyrometer and using an effective emissivity $\varepsilon_{\text {eff }}$ of 0.5 . Equation (1) was used:

$$
\begin{aligned}
\text { Radiation Efficiency (\%) } & =100 \times \frac{\text { radiation output }}{\text { thermal input }} \\
& =100 \times \frac{F A \varepsilon_{\text {eff }} \sigma\left(T_{s}{ }^{4}-T_{a}^{4}\right)}{\dot{V}_{\mathrm{CH}_{4}} \times C V_{\mathrm{CH}_{4}, \text { net }}}
\end{aligned}
$$

where $F$ is a view factor of around 0.6 which accounts for a section of the burner with square honeycomb monoliths. $A$ is the apparent area of the monolith at the open end, $\sigma$ is the Stephan-Boltzmann constant, $T_{s}$ is the average surface temperature and $T_{a}$ is the temperature of the surroundings. $\dot{V}_{\mathrm{CH}_{4}}$ is the volume flow rate of $\mathrm{CH}_{4}$ at STP and $\mathrm{CV}_{\mathrm{CH}_{4}, \text { net }}$ is the net calorific value of $\mathrm{CH}_{4}$ at STP (Dupont et al., 2000). The main composition of natural gas is methane. Here, the net calorific value of natural gas is $34.54 \mathrm{MJ} / \mathrm{Nm}^{3}$.

Figure 4 shows the radiation efficiency of the monolith alone between 4 and $13.09 \mathrm{~kW}$ in thermal input of catalytic burner.

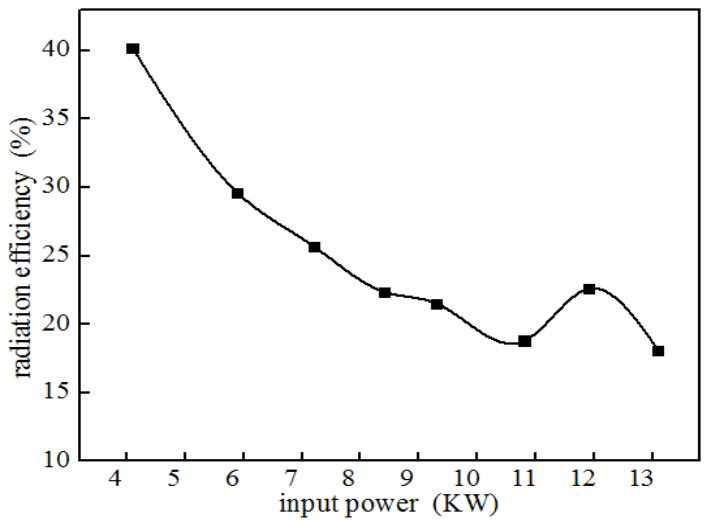

Fig. 4 Curves of the radiation efficiency in different thermal input of catalytic burner 
The radiation efficiency of the monolith alone varied from approximately $40 \%$ to $20 \%$ (for total thermal inputs of $4 \mathrm{~kW}$ and 10 $\mathrm{kW}$ respectively). As the thermal inputs increases, there has been a gradual drop in the radiation efficiency of the monolith alone up till 10 $\mathrm{kW}$. After that, the catalytic combustion of burner was not very steady.

\subsection{Radiation heat transfer of the catalytic combustion furnace}

When reaching a steady state of catalytic combustion, the monolith was a bright red. Radiation heat exchange between the surface of catalytic honeycomb monoliths and the wall surface in an enclosed furnace was regarded as the radiation heat exchange between two gray bodies in an enclosed cavity. It was calculated by Eq. (2):

$$
\phi_{1,2}=\frac{A_{1} \sigma\left(T_{1}^{4}-T_{2}^{4}\right)}{\left(\frac{1}{\varepsilon_{1}}-1\right)+\frac{1}{X_{1,2}}+\frac{A_{1}}{A_{2}}\left(\frac{1}{\varepsilon_{2}}-1\right)}
$$

where $\varepsilon_{1}$ is the emissivity of catalytic honeycomb monoliths surface, which was 0.5 , the wall surface was surrounded by heat sink, which $\varepsilon_{2}$ was $0.85, X_{1,2}$ is the shape factors, here was $1, A_{1}$ is the apparent area of the monolith at the open end, which was $A_{1}=0.15 \times 0.3=0.045 \mathrm{~m}^{2}$. The inner casing of furnace still had the shape of a cuboid, whose edges were $370 \mathrm{~mm}$ long, $150 \mathrm{~mm}$ wide and $300 \mathrm{~mm}$ high. $A_{2}$ is the apparent area of the wall surface, which is $A_{2}=0.378 \mathrm{~m}^{2} . T_{1}$ is the average surface temperature of monoliths, which was $1373 \mathrm{~K}$ (Zhang et al., 2008). $T_{2}$ is the average temperature of the wall surface, which was recorded approximately as $1173 \mathrm{~K}$ by thermocouple $\mathrm{K}$ of diameter 1 . At this moment natural gas flow rate was $8.5 \mathrm{~L} / \mathrm{min}$ (input power of $4.893 \mathrm{~kW}$ ), but partial thermal input was waste to the surroundings due to the construct of furnace system. The furnace here was supposed to be as an adiabatic system. Thus the radiation heat transfer of the catalytic combustion furnace is calculated to be $2.097 \mathrm{~kW}$. The radiation efficiency of the monolith alone is difference from that of the monolith in an enclosed furnace. Because an enclosed furnace which surrounds the monolith' s output in radiation could reflect or re-emit it entirely to heat sink in the furnace. So the values of the radiation of the monolith in an enclosed furnace is higher than that in figure 4. This high radiant heat exchange inside furnace had a key role to heating glazed tiles.

Figure 5 shows the glazed tile heated by the catalytic combustion furnace.

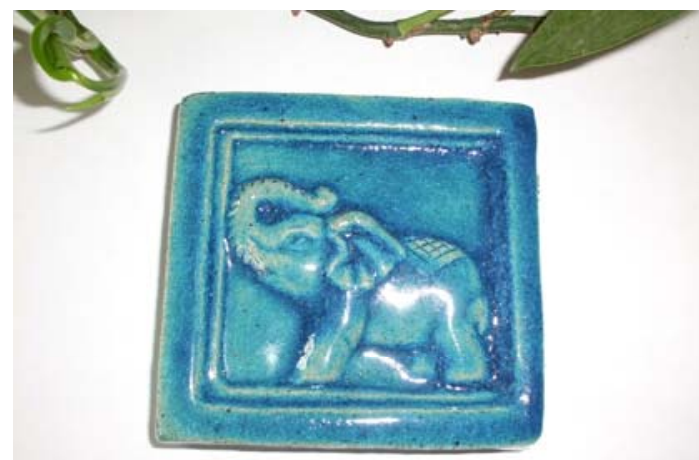

Fig. 5 Glazed tile heated by the catalytic combustion furnace

The glazed tiles possessed excellent color and luster of glaze surface. Overall, the glaze surface of the tile was very smooth, and it created a strong artistic atmosphere.

\subsection{Pollutant emissions of the catalytic combustion furnace}

Figure 6 plots exhaust gas pollutant emissions at exhaust sampling point of catalytic combustion furnace vent as time went on. At the time of the ignition we recorded it as zero at the same point which was connected with pipes of analysers.

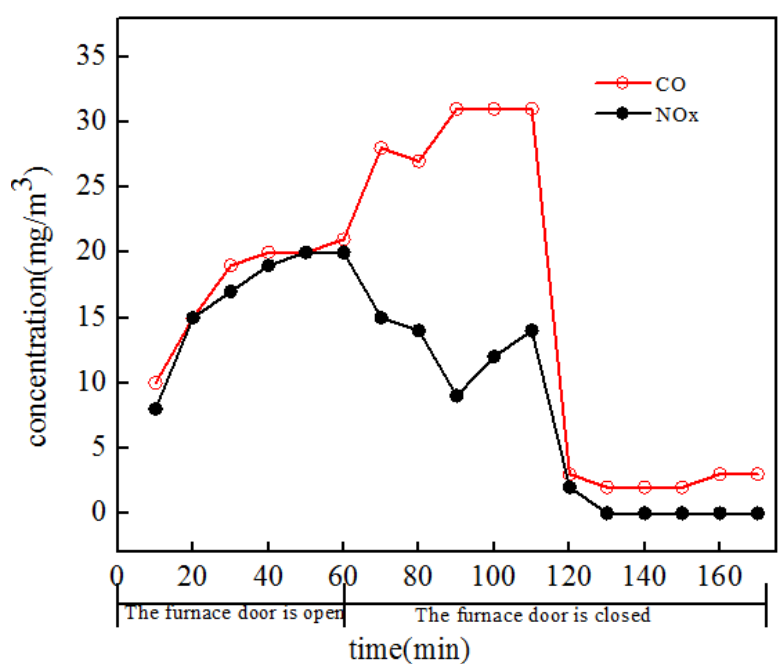

Fig. 6 curves of emissions in the exhaust gas of catalytic combustion furnace

It was shown that $\mathrm{NOx}$ rose during the first period of 60minutes due to the appeared flame influence of gas combustion. Then $\mathrm{NO}_{\mathrm{X}}$ decreased between 60 and 170 minutes. But the emission of $\mathrm{NO}$ xas low (below $20 \mathrm{mg} / \mathrm{m}^{3}$ ) because the exhaust gas had been significantly diluted before the furnace door closed. Then the catalytic combustion entered a steady state gradually with the decreasing $\mathrm{NO}$ x after 60 minutes. $\mathrm{NO}_{\mathrm{x}}$ dropped to near zero when regulated the flow rate of natural gas to $7.0 \mathrm{~L} / \mathrm{min}$ at 120 minutes, because the temperature is lower than that of the generation of $\mathrm{NOx}$ and the oxidation reaction of catalytic combustion is almost complete.

The emission of CO ascended gradually as time went on during the first period of 110 minutes. The maximum value of CO is $31 \mathrm{mg} / \mathrm{m}^{3}$. It was clear that the emission of $\mathrm{CO}$ was increasing faster after 60 minutes. Because there were $\mathrm{CO}$ selectivities for the fuel-rich concentrations (conditions of partial oxidation)during the start-up process. And CO was not diluted during the furnace door closed after 60 minutes. Similarly, when the burner reached a steady catalytic combustion state in the condition of lean-fuel, CO dropped to near zero at 120 minutes.

\subsection{Influence of the exhaust gas to plant growth}

The experiments were carried out twelve times, spending six month. The average height of all plants is $19 \mathrm{~cm}$ and their statements were basically same and there was no branches had grown in all four schefflera plants before experiment. And four schefflera plants all grew well after the last experiment. The growth statements of all plants were shown in Fig. 7.

Fig. 7(a) and 7(b) directly showed that schefflera plants growth status in experimental group and control group after the sixth time experiment. The average height of two groups is still $19 \mathrm{~cm}$, which do not change apparently. It was concluded that exhaust gas of catalytic combustion does not have obvious effect on boosting plant growth at that time. There are four new branches in Fig. 7(c), twice as much as it shown in Fig. 7(d). Schefflera plant in experimental group grew more sprouts than that in control group, which means the exhaust gas of catalytic combustion could help new branches grow faster. After amonth experiment, the result showed difference of growth statement between two groups. Sequentially, the experiments were done for another six times during the period of five month. The average height of experimental group increased to $22 \mathrm{~cm}$, higher by $3 \mathrm{~cm}$ than that of con- 


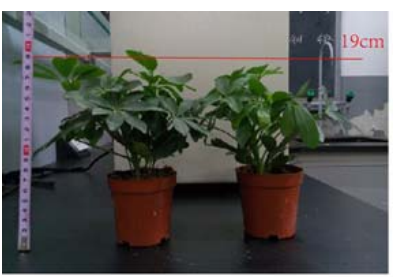

(a)

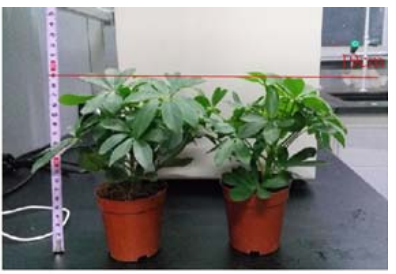

(b)

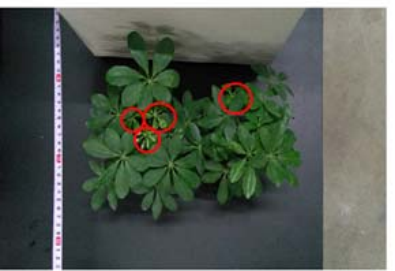

(c)

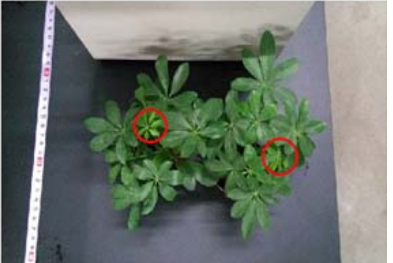

(d)

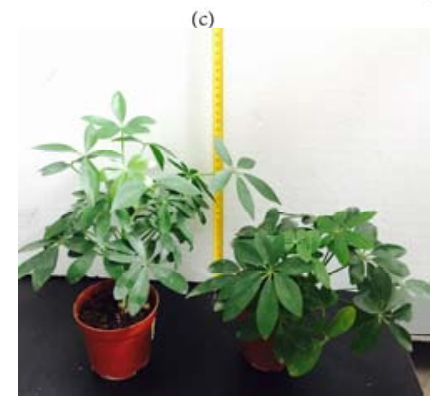

(e)

Fig. 7 (a)Schefflera plant growth status in experimental group after the sixth experiment, (b)Schefflera plant growth status in control goup after the sixth experiment, (c)Sprouts in experimental group after the sixth experiment, (d)Sprouts in control group after the sixth experiment, and(e) Schefflera plant growth status of the experimental group(left)and the control group(right) after the last experiment.

trol group shown in Fig. 7(e). The result showed that schefflera plant in experimental group grow taller and greener.

The temperature in greenhouse shown in Fig 8 at atmospheric pressure and at steady state was studied experimentally. The temperature change between $27.5^{\circ} \mathrm{C}$ to $29.5^{\circ} \mathrm{C}$ when environment temperature and humidity were $26.5{ }^{\circ} \mathrm{C}$ and $41 \% \mathrm{RH}$ respectively.

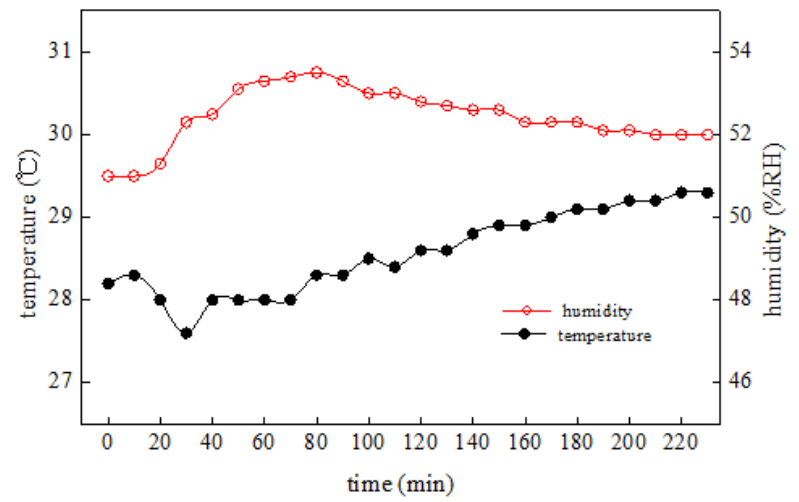

Fig. 8 Curves of temperature and humidity in greenhouse

The temperature in greenhouse rose slowly due to closing the furnace door after 70 minutes. During the whole experiment, the change of temperature is very small, which is close to room temperature. While the humidity in greenhouse shed varying from $50 \% \mathrm{RH}$ to $54 \% \mathrm{RH}$ also was showed in figure 8 . The humidity began to rise slightly after closing the furnace door at 70 minutes because there was a large amount of water vapor generation during combustion.

Figure 9 plots the concentration of $\mathrm{CO}_{2}$ inside greenhouse. $\mathrm{CO}_{2}$ increased before 70 minutes, then it changed between $3850 \mathrm{mg} / \mathrm{m}^{3}$ and $3950 \mathrm{mg} / \mathrm{m}^{3}$ after 70 minutes. Obviously, the $\mathrm{CO}_{2}$ content of greenhouse was much higher than that of indoor air due to carbon dioxide produced by catalytic combustion.

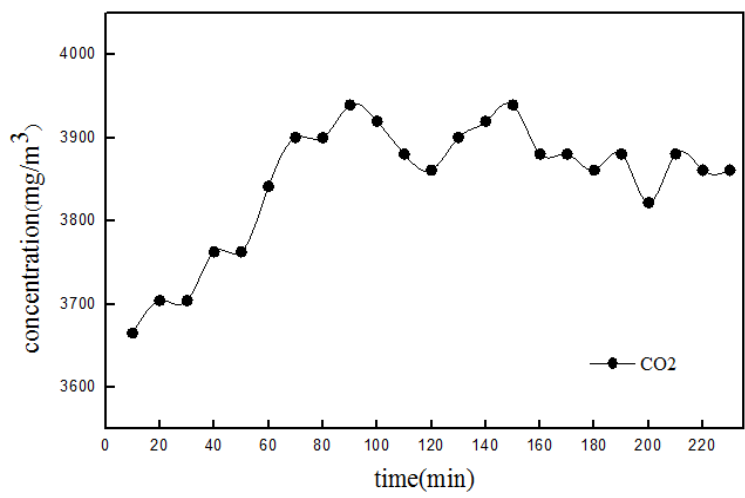

Fig. 9 Curves of the $\mathrm{CO}_{2}$ content in the greenhouse shed

\section{CONCLUSIONS}

The radiation fluxes of catalytic burner were higher than that of conventional one because of high apparent area surface of catalytic monolith. The radiation efficiency of the monolith alone varied from approximately $20 \%$ to $40 \%$. The radiation characteristics of the catalytic combustion furnace were analyzed by calculating radiation heat transfer in an enclosed furnace. It was found that the high radiation heat transfer in an enclosed furnace played an important role to heating glazed tiles. The glazed tile products heated by the catalytic combustion furnace are more smooth and glossy than that of conventional ones. At the same time its bisque was combined with glaze very well. Furthermore, it proved that the pollutant emissions (NOx and $\mathrm{CO}$ ) of exhaust gas were closed to zero while the catalytic combustion of furnace reached a steady state.

Besides, the influence of catalytic combustion exhaust gas to plant was also discussed by means of comparison. The schefflera plant in experimental group grew more sprouts and taller than that in control group. The exhaust gas of catalytic combustion with $6 \%$ carbon dioxide has a promotion effect on the growth of schefflera plants. The exhaust gas of catalytic combustion furnace could be applied to agriculturegreenhouses. It indicated the advantages of energy-saving and environmental protection for the catalytic combustion. Catalytic combustion played an increasingly important role for lower carbon emissions in industrial applications.

\section{ACKNOWLEDGMENT}

The project was sponsored by the Beijing Municipality Key Lab of Heating, Gas Supply, Ventilating and Air Conditioning Engineering and Collaborative Innovation Center of Key Technologies of Energy Saving and Emission Reduction.

\section{NOMENCLATURE}

$A \quad$ apparent area of the monolith at the open end $\left(\mathrm{m}^{2}\right)$

$A_{1} \quad$ apparent area of the monolith at the open end $\left(\mathrm{m}^{2}\right)$

$A_{2} \quad$ apparent area of the wall surface $\left(\mathrm{m}^{2}\right)$

$\mathrm{CV}_{\mathrm{CH}_{4}, \text { net }} \quad$ net calorific value of $\mathrm{CH} 4$

$F \quad$ view factor

$\dot{V}_{\mathrm{CH}_{4}} \quad$ volume flow rate of $\mathrm{CH}_{4}\left(\mathrm{~N} \cdot \mathrm{m}^{3} / \mathrm{s}\right)$

$X_{1,2} \quad$ shape factors 
$T_{a} \quad$ temperature of the surroundings (K)

$T_{s} \quad$ average surface temperature (K)

$T_{1} \quad$ average surface temperature of monoliths (K)

$T_{2} \quad$ average temperature of the wall surface (K)

\section{Greek Symbols}

$\Phi_{1,2} \quad$ radiation heat exchange (kW)

$\varepsilon_{1} \quad$ emissivity of catalytic honeycomb monoliths surface

$\varepsilon 2$ emissivity of wall surface

$\varepsilon_{\mathrm{eff}} \quad$ effective emissivity

$\sigma \quad$ the Stephan-Boltzmann constant

\section{REFERENCES}

Carroni, R., Griffin, T., Mantzaras, J., and Reinke, M., 2003, "HighPressure Experiments and Modeling of Methane/Air Catalytic Combustion for Power-Generation Applications," Catalysis Today, 83(1-4), 157-170.

http://dx.doi.org/10.1016/S0920-5861(03)00226-8

Cohen, A. J., Ross, A. H. B., Pandey, K. D., Krzyzanowski, M., Kunzli, N., and Gutschmidt, K., et al. 2005, "The Global Burden of Disease Due to Outdoor Air Pollution,” Journal of Toxicology \& Environmental Health Part A, 68(13-14), 1301-7.

http://www.tandfonline.com/doi/abs/10.1080/15287390590936166

Dupont, V., Moallemi, F., Williams, A., and Zhang, S. H., 2000, "Combustion of Methane in Catalytic Honeycomb Monolith Burners," International Journal of Energy Research, 24(13), 1181-1201. http://dx.doi.org/10.1002/1099-114X(20001025)24:13<1181::AIDER669>3.0.CO;2-Y

Duque, L., Relvas, H., Silveira, C., Ferreira, J., Monteiro, A., and Gama, C., Rafael, S., Freitas, S., Borrego, C., Miranda, A.I. 2016, "Evaluating Strategies to Reduce Urban Air Pollution," Atmospheric Environment, 127, 196-204.

http://dx.doi.org/10.1016/j.atmosenv.2015.12.043

Jannasch, A. K., Silversand, F., Berger, M., Dupuis, D., and Tena, E., 2006, "Development of a Novel Catalytic Burner for Natural Gas
Combustion for Gas Stove and Cooking Plate Applications," Catalysis Today, 117(4), 433-437. http://dx.doi.org/10.1016/j.cattod.2006.06.020

Kirillov, V. A., Kuzin, N. A., Kulikov, A. V., Fadeev, S. I., Shigarov, A. B., and Sobyanin, V. A., 2003, "Thermally Coupled Catalytic Reactor for Steam Reforming of Methane and Liquid Hydrocarbons: Experiment and Mathematical Modeling," Theoretical Foundations of Chemical Engineering, 37(3), 276-284. http://dx.doi.org/10.1023/A:1024039823317

Pfefferle, W. C., 1975, “Catalytically-Supported Thermal Combustion,” US, US3928961.

Pfefferle, W. C., 1978, "The Catalytic Combustor - an Approach to Cleaner Combustion (by Reaction Control in Gas Turbine Engines)," Journal of Energy, 2(3), 142-146. http://dx.doi.org/10.2514/3.47964

Pfefferle, L.D., and Pfefferle, W.C., 1987, "Catalysis in Combustion,” Catalysis Reviews, 29(2-3), 219-267. http://dx.doi.org/10.1080/01614948708078071

Pontelli, G. C., Reolon, R. P., and Alves, A. K., 2011, “Application of Cerium Oxide Electrospun Fibers in the Catalytic Combustion of Methane," Applied Catalysis A General, 405(1), 79-83. http://dx.doi.org/10.1016/j.apcata.2011.07.029

Rückerl, R., Schneider, A., Breitner, S., Cyrys, J., and Peters, A., 2011, "Health Effects of Particulate Air Pollution: a Review of Epidemiological Evidence,” Inhalation Toxicology, 23(10), 555-92. http://dx.doi.org/10.3109/08958378.2011.593587

Zhang, S.H., Dupont, V., Zhou, Q., and Williams, A., 2008, "Mechanisms and Applications of Catalytic Combustion of Natural Gas with Near- Zero Pollutant Emissions,” Science Press, Beijing, China.

Zhang, S. and Li, N., 2010, "Research on Mechanisms and Applications of Catalytic Combustion of Natural Gas," Frontiers in Heat \& Mass Transfer, 2(3), 1-6.

http://dx.doi.org/10.1115/IHTC14-22044 